\title{
Aspectual auxiliary verbs in Xitsonga
}

Seunghun J. Lee

Central Connecticut State University, USA | University of Johannesburg, South Africa | International Christian University, Tokyo, Japan

E-mail: seunghunjlee@gmail.com

Crous Hlungwani

University of Venda, Thohoyandou, South Africa

E-mail: crous.hlungwane@univen.ac.za

\begin{abstract}
In Xitsonga, certain Aspectual Auxiliary verbs (AA verbs) appear with double subject agreement. While these AA verbs have been reported in the description of Xitsonga (Baumbach 1987: 250-252), a systematic morphosyntactic study of these constructions has not been undertaken. This study aims to fill this gap. An AA verb is marked with tense, aspect, mood, negation and relative clause markers and may occur in wh-questions. The lexical verb following the AA verb may be the target of verbal extensions (applicative and reciprocal), reflexive, causative and passive markers.
\end{abstract}

Keywords: Aspectual Auxiliary (AA) verbs, Xitsonga, morphosyntax, doubling of subject agreement

\section{Introduction}

Consider the following sentences with and without the Aspectual Auxiliary verb (AA verb) $d z u m b a$ 'always'. The auxiliary verb construction has two subject agreement markers, one before the auxiliary and one before the lexical verb. 
(1) AA verb
a. ndzì nwá mátí
$1 \mathrm{SG}^{1}$ drink water
'I drink water'
b. ndzì dzúmbá ndzí nwá mátí
1SG ALWAYS 1SG drink water
'I always drink water' (literally, 'I always I drink water')

The AA construction in (1b) is productive in Xitsonga (Marivate, Mathumba and Mabaso 1990: 22). However, descriptions relating to the kinds of morphosyntactic characteristics this construction has are insufficient. This paper aims to fill this gap by supplying data on various morphosyntactic constructions.

Complex verbal constructions, such as AA constructions, are not uncommon in Bantu languages. Gibson and Marten (2015) report that AA verbs inflect for temporal information in Swahili (2a), while lexical verbs may express aspectual information in Rangi (2b). In addition, double subject markers can be obligatory (Swahili and Rangi) or optional (siSwati).

(2) Complex verbal constructions in other Bantu languages (Gibson and Marten 2015)

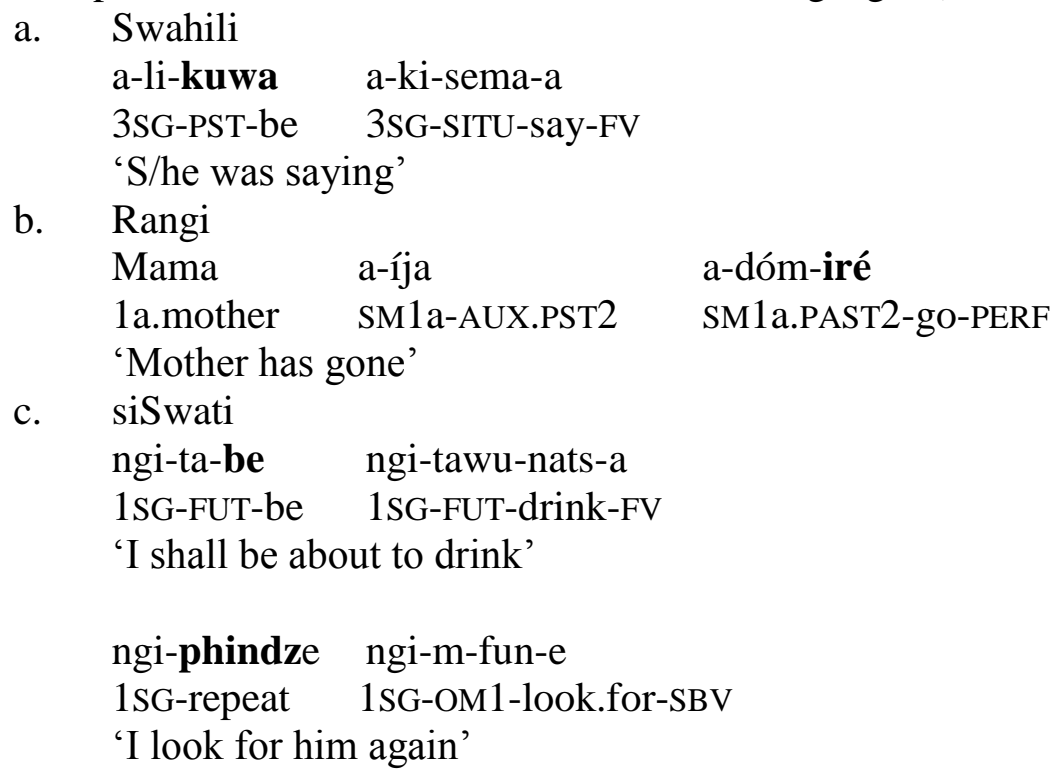

Xitsonga has siSwati-type AA verbs. In (3a) both the AA verb and the lexical verb is preceded by subject agreement. Some AA verbs are followed by the infinitive $k u$ as in (3b). AA verbs can belong to only one of these two types. Here, we focus on the doubling type in (3a).

\footnotetext{
${ }^{1}$ The abbreviations used in this paper are as follows: $\mathrm{SM}=$ subject marker, $\mathrm{PST}=$ past tense, $\mathrm{SITU}=$ situational, $\mathrm{FV}=$ final vowel, $\mathrm{SG}=$ singular, $\mathrm{PL}=$ plural, AUX=auxiliary, $\mathrm{PERF}=$ perfective, $\mathrm{FUT}=$ future, $\mathrm{OM}=$ object marker, $\mathrm{SBV}=$ subjunctive, $\mathrm{PROG}=$ progressive, $\mathrm{PERST}=$ persistive, $\mathrm{OPT}=$ optative, $\mathrm{NEG}=$ negative, $\mathrm{CL}=$ class prefix, $\mathrm{REL}=$ relative clause, $\mathrm{FOC}=$ focus marker, STAT=stative, APPL=applicative, INF=infinitive, RECP=reciprocal, REFL=reflexive, RED=reduplicant, PASS=passive, CAUS=causative, $\mathrm{SBJ}=$ subkect number=noun class or person marking. An acute accent on a vowel marks a high tone, and a grave accent marks a low tone. Only grammatical sentences are marked with tone. Examples are written using the Standard Orthography of Xitsonga. The data presented is by the second author unless noted otherwise.
} 
(3) Aspectual auxiliary verb constructions in Xitsonga

a. Type 1: doubling of the subject agreement

Subject $t_{i}-$ Aspectual auxiliary - Subject $_{i}-$ Lexical verb (in infinitive)

ndzì dzúmbá ndzí nwá mátí

1SG always $1 \mathrm{SG}$ drink water

'I always drink water' (literally, 'I always I drink water')

b. Type 2: no-doubling of the subject agreement

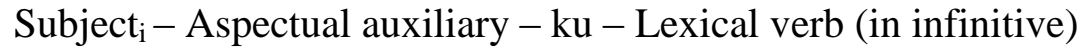

hì tálá kú vá vóná làhà

1PL always INF OM3PL see here

'We always see them here.' (literally, 'We always to see them here')

In the literature on southern Bantu languages, AA verbs are also known as deficient verbs. Anderson (2011) reports an extensive survey of auxiliary verb constructions in African languages. In this report, Xhosa examples with AA verbs appear with the gloss CONTINUATIVE. Gibson and Marten (2015: 20) discuss AA verbs in siSwati (Taljaard Khumalo and Bosch 1991, Ziervogel and Mabuza 1976). Gibson and Marten also refer to studies of AA verbs in Zulu (Doke 1992: 202-214, Zeller 2006), Xhosa (du Plessis and Visser 1992) and Tswana (Cole 1955: 191, 236, 286). Following Nurse (2008: 29, 59), the AA construction can be classified as a two-word structure, and the AA construction in type 1 illustrated in (3a) - is less common than type 2 - in (3b). Expanding from these previous studies, the current paper examines morphosyntactic characteristics (Nurse 2008: 43-46) of AA verb constructions.

Basic patterns of AA verbs in Xitsonga are presented in section 2. In section 3, grammatical structure associated with AA verbs are introduced, while grammatical structures associated with the lexical verbs are discussed in section 4. Additional structures are presented in section 5.

\section{Basic patterns}

Xitsonga AA verbs show a 'split/double inflectional' pattern (Anderson 2011: 42). It is split because tense, aspect, object and negative marking can appear with AA verbs, and it is double because of double subject agreement marking. The subject agreement preceding an AA verb and the following lexical verb must agree in person and number (4a-f). Morphologically, the second subject marker copies the form of the first subject marking except in third person singular (4c), in which the second subject marker is marked with $a$ (instead of a copy of $u$ ).

(4) Basic agreement pattern

a. ndzì dzùmbà ndzì nwà màtì $\left(I^{s t} s g\right)$

'I always drink water

b. ù dzùmbà ù nwà màtì $\left(2^{\text {nd }} s g\right)$

'You always drink water' 


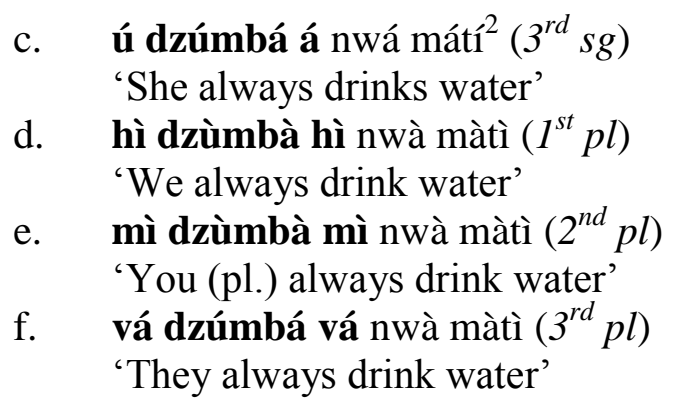

Sentences containing the AA verbs are ungrammatical when the subject markings do not agree (5a). Both subject markings are required as shown in $(5 b-c)$.

(5) Illicit agreement pattern
a. * *ndzì dzúmbá hí nwá mátí
b. *ndzì dzúmbá nwá mátí
mismatch of subject agreement
c. *dzumba ndzi nwa mati
no doubling
no doubling

It is odd to substitute the subject agreement of the lexical verb with the infinitive marker $k u$ 'to' (6a). If the second agreement is $k u$, the verb dzumba must take an applicative suffix (6b), but the second agreement now cannot be the same as the first agreement (6c).

(6) Illicit agreement pattern
a. $\quad$ ??? ndzì dzùmbà kù nwà màtì
b. Ndzì dzùmbèlà kù nwà màtì
c. *ndzi dzumbela ndzi nwa mati
'I keep on drinking water' (similar to Type 2)

Xitsonga has a number of AA verbs that belong to type 1 and type 2 as shown in (7). The meaning of these AA verbs often corresponds to aspectual, temporal or modal adverbs in English. The semantic characterisation of these verbs are based on Gibson and Marten (2015). AA verbs may have a separate use as a lexical verb as shown in the last column of (7). The $*$ sign indicates words or meanings that do not appear in the Tsonga-English dictionary (Cuenod 1967). Examples of $\div$ AA verbs are provided in the appendix.

(7) List of aspectual auxiliary verbs in Xitsonga (Baumbach 1987: 250-252)

\begin{tabular}{|l|l|l|l|}
\hline Type 1 & as an AA verb & Semantics & as a lexical verb \\
\hline ku dzúmba & always & aspectual & to spend time, relax \\
\hline ku èngeta & do again & aspectual & to increase, add \\
\hline ku hámba & do always, continually & aspectual & $n / a^{\bullet}$ \\
\hline ku hàtla & do quickly & aspectual & to hasten, hurry \\
\hline ku tàmà & always, do continually & aspectual & $n / a^{\bullet}$ \\
\hline ku tlhèlà & also & aspectual & to return, to go back \\
\hline ku tsháma & always & aspectual & to sit down, stay \\
\hline
\end{tabular}

\footnotetext{
2 A reviewer mentioned that this difference in the subject marking ( $u$ - vs. $a$-) is sometimes called 'antiagreement'. For formal analysis on this issue, see Henderson (2013) and Schneider-Zioga (2007). Another reviewer suggested that the different subject marking might be because the main verb in the AA construction is in the participial mood. We thank both reviewers who drew our attention to these explanations.
} 


\begin{tabular}{|l|l|l|l|}
\hline ku tshìka & by chance, unexpectedly & aspectual & to leave \\
\hline ku kála, ku ká & until, ultimately & temporal & to have a scarcity of, to lack \\
\hline ku kánga & never & temporal & \\
\hline ku khànga & once & temporal & \\
\hline ku kóndza & until, eventually & temporal & to go and reach \\
\hline ku pfà & in the meantime & temporal & to come from \\
\hline ku vhèla & now & temporal & \\
\hline ku zà & never & temporal & \\
\hline ku zànga & never before & temporal & \\
\hline ku jínga & nevertheless & modal & $n / a^{\bullet}$ \\
\hline ku tshùkà & it may happen that & modal & to start in surprise \\
\hline Type 2 & \multicolumn{3}{|l|}{} \\
\hline ku phòse & nearly & aspectual & \\
\hline ku tála & likely & aspectual & to become full \\
\hline ku tshámela & always & aspectual & to wait for someone \\
\hline ku phìka & always, continually & aspectual & to dispute what another says \\
\hline
\end{tabular}

All noun classes can appear with AA verbs (8). The second agreement of class 1 has a morphologically different form as already seen in (4c). The double subject markings before AA verbs and lexical verbs are identical for all other noun classes.

(8) Noun classes and agreements

a. mù-nhù ú dzúmbá á dyà vùswà

class 1

CL1-man SM1 always SM1 eat porridge

'a person always eats porridge'

b. và-nhù vá dzúmbá vá dyà vùswà

class 2

CL2-man SM2 always SM2 eat porridge

'people always eat porridge'

c. mù-tì wú dzúmbá wú míyélá nìvùsìkù

CL3-village SM3 always SM3 quiet at.night

'a village always becomes quiet at night'

d. mì-tì yí dzúmbá yí rí ní hùwà

CL4-village SM4 always SM4 be with noise

'villages are always noisy'

e. rìtó rí dzúmbá ní vúlá xókárhì

class 5

word SM5 always SM5 mean something

'a word always means something'

f. mà-rìtó má dzúmbá má húmélélá éká phéphàhùngù class 6

CL6-word SM6 always SM6 appear in newspaper

'words always appear in newspaper'

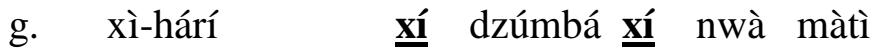

class 7

CL7-wild.animal SM7 always SM7 drink water

class 3

'a wild animal always drinks water'

h. swì-hárí swí dzúmbá swí nwá mátì

class 8

cl8-wild.animal SM8 always SM8 drink water

class 4

'wild animals always drink water'

i. n-gùlùvè yí dzúmbá yí nwà màtí

class 9

CL9-pig SM9 always SM9 drink water

'a pig always drinks water' 
j. tì-ngùlùvè tí dzúmbá tí nwà màtì class 10 CL10-pig SM10 always SM10 drink water 'pigs always drink water'

k. rì-rìmí $\underline{\text { rí dzúmbá rí rí ní xítátísí }}$ class 11 CL11-language SM11 always SM11 have with consonant 'a language always has a consonant'

1. tì-ndzímí 任 dzúmbá tí rí ní và-vúlávúrí class 10 CL10-language SM10 always SM10 have with CL2-speakers 'languages always have speakers'

m. vù-vábyí byí hátlá byí hángáláká class 13 CL13-illness SM13 quickly SM13 spread 'illness quickly spreads'

n. mà-vábyí mà hàtlà mà hàngàlàkà class 6 CL6-illness SM6 quickly $\overrightarrow{\mathrm{SM} 6}$ spread (as plural of class 13) 'illnesses quickly spread'

o. kù lwà kú hátlá $\underline{\text { kú hèlà }}$ class 15 CL15 fight SM15 quickly SM15 end 'fighting quickly ends'

Next, we turn to the question of whether AA verbs form a single unit or whether they can be split by an intervening phrase. By default, the prepositional phrase (PP) na munghana 'with a friend' appears at the end of a sentence (9a). When this phrase is fronted, a pause is required after the phrase as in (9b). The phrase may follow AA verbs as illustrated in (9c), but a pause cannot be inserted. When there is a pause (marked by //) after the PP as in (9d), the AA reading is not available. Another diagnostic for the phrasal status of AA verbs comes from penultimate lengthening (marked with :) at the end of a phrase. Expectedly, penultimate lengthening is required in $(9 \mathrm{~b})$ before a pause; the absence of penultimate lengthening results in a prosodically ungrammatical sentence. Penultimate lengthening produces less categorical judgement than pauses; the presence of pause after PP is ungrammatical (9d), but the presence of penultimate lengthening is allowed $(9 \mathrm{c})$.

(9) Intervention by a phrase

a. ndzì hàtlà ndzí nwà byàlwà nà mú-nghá:nà

1SG quickly 1 SG drink beer with CL1-friend 'I quickly drink beer with a friend'

b. ná múnghá:nà, // ndzì hàtlà ndzí nwá byàlwà (a pause // is required)

c. ndzì hàtlà ná múnghá(:)nà ndzí nwá byàlwà

d. *ndzi hatla na mungha:na // ndzi nwa byalwa (a pause // is prohibited)

When an AA verb also has a meaning of a lexical verb, the sentence is ambiguous (10a). A pause after the PP only allows dzumba to be interpreted as a lexical verb (10b).

(10) The case of $d z u ́ m b \grave{a}$

a. ndzì dzúmbá ná múnghánà ndzì nwà byàlwà ambiguous

'I am relaxing with a friend drinking beer' (dzumba as a lexical verb, default reading)

'I always drink beer with a friend' (also possible, as an AA verb) 

b. ndzì dzúmbá ná múnghánà // ndzì nwà byàlwà only as a lexical verb 'I am relaxing with a friend drinking beer'
'*I always drink beer with a friend'

This section described basic aspects of AA verbs concerning the patterns of double subject markers, types of AA verbs and pauses in the AA construction. Section 3 examines various syntactic configurations that appear with AA verbs, and Section 4 presents constructions that can only appear with the lexical verb.

\section{Aspectual auxiliary verb as a target}

AA verbs are marked for tense, aspect, mood and negation. When AA verbs occur in a relative clause, the AA verb is marked with the relative clause marker.

\subsection{Tense markers}

The future tense marker $t a$ appears before an AA verb as in (11a). This future marker cannot appear before the lexical verb (11b), nor can it appear before both verbs (11c).

(11) Future tense: $t a$
a. ndzì tà hàtlà ndzí nwá mátì
1SG FUT quickly 1 SG drink water
'I will quickly drink water'
b. *ndzi hatla ndzi ta nwa mati ${ }^{3}$
c. *ndzi ta hatla ndzi ta nwa mati

Yet, not all AA verbs are compatible with the future tense $t a$. AA verbs that make specific reference to the past cannot be used with the $t a$ tense. Future tense can be used with AA verb as in (12a) and (12b). However, the AA verbs in (12c, d) denote an event in the past; they cannot co-occur with the future tense marker ta (the same restriction holds for khanga 'once' and zanga 'never').

(12) Aspectual auxiliary verb with modal meaning
a. ndzì tà kóndzá ndzí vúyá lókó xí-kóló xí pfálà
1SG FUT eventually 1SG come.back when CL7-school SM7 close
'I will eventually come back when the school closes'
b. ú tá jíngá á vúyá hí khísímúsì
3SG FUT at.least 3SG come.back during christmas
'He at least comes back during Christmas'

\footnotetext{
a. ndzì hàtlà ndzí tá nwá mátì 1SG quickly 1 SG come drink water 'I quickly come to drink water'

b. ndzì tà hàtlà ndzí tá nwá mátì 1SG FUT quickly 1SG come drink water 'I will quickly come to drink water'
}

${ }^{3}$ These two sentences are grammatical if $t a$ is the lexical verb $k u$ ta 'to come' as shown below. 


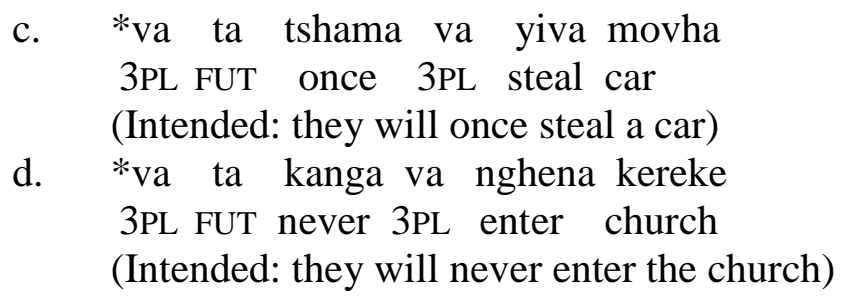

\subsection{Aspect markers}

In Xitsonga, aspects such as perfect, progressive and persistive are also marked on the AA verb, different from the language reported in Gibson and Marten (2015), in which aspect markers appear on the lexical verb.

The perfect/past tense suffix -ile is attached to the AA verb (13a). The -ile suffix cannot attach to the lexical verb (13b), nor can it appear in both positions (13c).

(13) Perfect/past tense: -ile
a. ndzì hàtl-ílé ndzì nwà màtì
1SG quickly-PST 1SG drink water
'I have quickly drunk water'
b. *ndzi hatla ndzi nw-ile mati 1SG quickly 1SG drink-PST water
c. *ndzi hatl-ile ndzi nw-ile mati
1SG quickly-PST $1 \mathrm{SG}$ drink-PST water

The -ile suffix can denote simple past as well as perfect tense. The phrase hi nkarhi wolowo 'at that time' can be used as a diagnosis for simple past (14).

(14) Simple past with -ile

hì hàtl-ílé hí dyá vúswà hì nkàrhí wólówó

1PL quickly-PST 1PL eat porridge at time that

'we quickly ate porridge at that time'

The phrase 'since my childhood', which denotes an event continuing from the past, can be used to diagnose the perfect use of the -ile suffix as in (15).

(15) Perfect with -ile

hì hàtl-1́lé hí dyá vúswà kù sùkèlà évúhlángíní byá hìná 1PL quickly-PST 1PL eat porridge since childhood of ours 'we have quickly eaten porridge since our childhood'

More examples of AA verbs with the -ile suffix are shown in (16).

(16) Aspectual auxiliary verbs with other meanings (perfect/past)
a. ndzì kóndz-ílé
ndzí vúyà
lòkò xì-kòlò
1SG eventually-PST 1SG come.back when CL7-school SM7 close
'I eventually came back when the school closes' 


\section{b. ú jíng-ílé á vúyà hì khísímúsì \\ 3SG at.least-PST 3SG come.back by christmas \\ 'He at least came back by Christmas'}

In AA constructions, the -ile suffix attaches to the lexical verb when the verb has a stative reading as in (17).

(17) AA verbs and lexical verbs with stative reading
a. ú tshámá á pháphám-ílé
3SG always 3SG awake-STATIVE
'He is always awake'
b. ngùlùvè yí dzúmbá yí nón-ílé
pig CL9 always CL9 be.fat-STATIVE
'The pig is always fat'

Progressive in Xitsonga is marked with a periphrastic construction: le ku V-eni ( $k a$ ) as in (18a). This progressive is marked on the AA verb (18b), and it cannot attach to the lexical verb (18c).

(18) Progressive constructions
a. ndzì lé kù nw-ènì ka mátí
1SG PROG drink-PROG water
'I am drinking water'
b. ndzì lé kù hàtl-ènì ndzí nwá mátí
1SG PROG quickly-PROG 1SG drink water
'I am quickly drinking water'
c. *ndzi hatla ndzi le ku nw-eni ka mati

Persistive aspect is expressed by the complex form: - a ha ri ku V-eni. This aspect marker also attaches to the AA verb (19a). It cannot attach to the lexical verb (19b).

(19) Persistive construction
a. ndz-à hà rí kú hátlís-énì ndzí nwá byálwà
1SG-PERST quickly-PERST 1SG drink beer
'I am still drinking beer quickly'
b. *ndzi hatla ndz-a ha ri ku nweni ka byalwa

More examples of the persistive marker $-a$ ha- 'still' are shown in (20). The third person singular subject $w a$ is a contracted form of $u$ and $a{ }^{4}$

(20) AA verbs with -ha 'still'
a. wá há pfá
á khíyá rí-vàntì
3SG STILL in.the.mean.time 3SG lock CL11-door
'He is still locking the door in the meantime'

\footnotetext{
${ }^{4}$ We thank Will Bennett for pointing this construction out to us (p.c. William Bennett).
} 


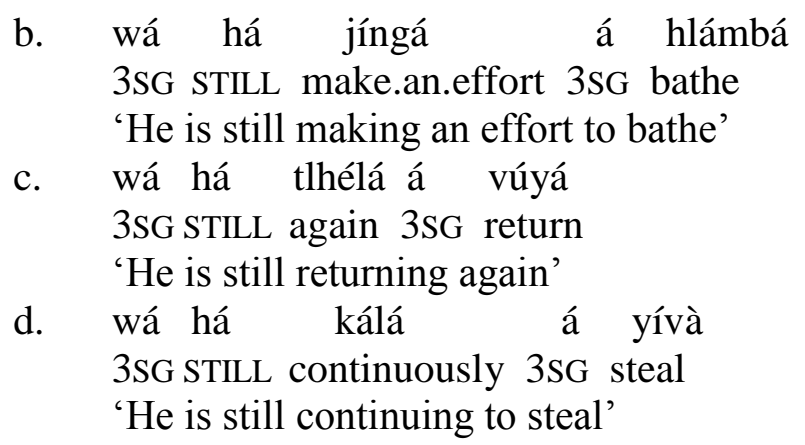

\subsection{Mood markers}

AA verbs are combined with the modals: ABILITY (CAN: $n g a$ ), POSSIBILITY (WOULD: $a$-SBJ- $t a$ V) and OBLIGATION (MUST: fanele $\mathrm{ku}$ ). The mood markers attach to the auxiliary verbs (21a, 22a, $23 a)$, and not the lexical verb (21b, 22b, 23b).

(21) ABILITY (CAN)
a. ndzí ngá hàtlà ndzí nwá mátí
1SG CAN quickly $1 \mathrm{SG}$ drink water
'I can quickly drink water'
b. $\quad *$ ndzi hatla ndzi nga nwa mati

(22) POSSIBILITY (WOULD)
a. á ndzí tá hàtlà ndzí nwá mátí PST 1SG FUT quickly 1SG drink water 'I would quickly drink water'
b. *ndzi hatla a ndzi ta nwa mati

(23) OBLIGATION (MUST) ${ }^{5}$
a. ndzì fánélé kú hàtlà ndzí nwá mátí 1SG MUST quickly $1 \mathrm{SG}$ drink water 'I must quickly drink water'
b. *ndzi hatla ndzi fanele ku nwa mati

Optative in Xitsonga is constructed as $a$ SBJ V-e $(n i)$, and is marked on the AA verb $(24 \mathrm{a}, \mathrm{c}, \mathrm{d}, \mathrm{e})$. The optative cannot be marked on the lexical verb (24b).

(24) Optative
a. á hí hátl-é(ní) hí nwá mátí
OPT 1PL quickly-OPT 1PL drink water 'Let's quickly drink water'
b. *a hi hatla hi nweni mati

\footnotetext{
${ }^{5}$ William Bennett (p.c.) suggested that the fanele $k u$ construction in Xitsonga might be similar to isiXhosa, in which the construction take the form of ku-fanele ndi-Verb. However, the second author, attested that the $k u$ fanelel $n d z i$ Verb construction, with a post-verbal subject, in Xitsonga is ungrammatical.
} 


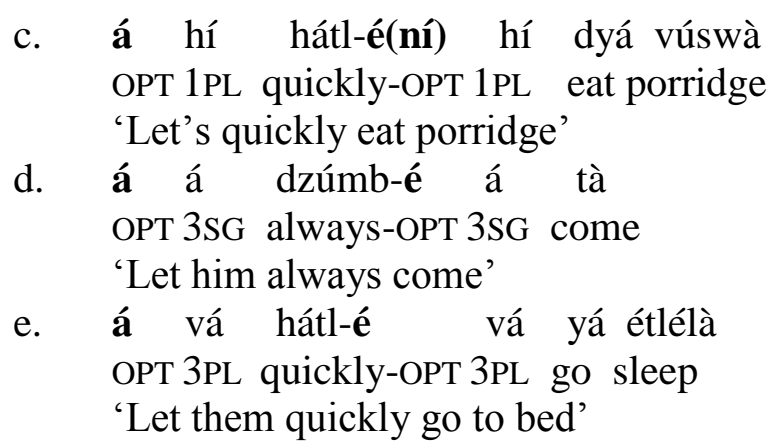

\subsection{Negative markers}

Negation is marked on AA verbs. The auxiliary verb hatla 'quickly' is negated in three tenses below: present negative (25a), perfect negative (25c) and future negative (25e). Negative markers may not attach to the lexical verb $(25 \mathrm{~b}, \mathrm{~d}, \mathrm{f})$.

(25) Negation in three tenses
a. à ndzí hàtl-ì ndzì nwà màtì
NEG 1SG quickly-NEG 1SG drink water
'I don't quickly drink water'
b. *ndzi hatla a ndzi nwi mati
c. à ndzí hàtl-àngì ndzí nwà màtì past neg.
NEG 1SG quickly-PST.NEG 1SG drink water
'I didn't quickly drink water'
d. *ndzi hatla a ndzi nwangi mati
NEG 1SG FUT.NEG quickly-NEG 1SG drink water 'I will not quickly drink water'
f. *ndzi hatla a ndzi nge nwi mati
e. à ndzí ngé hàtl-ì ndzì nwà màtì
present neg.
future neg.

In affirmative sentences, the perfect/past suffix -ile must appear on the AA verb. In negative sentences, the -ile suffix can appear on the lexical verb $(26 a, b)$ in sentences that denote the perfect tense only. Adding a simple past phrase such as hi nkarhi wolowo 'at that time' to $(26 a, b)$ results in ungrammatical sentences as shown in (26c) and (26d), respectively.

(26) Perfect negation
a. à hí hàtl-àngì hí nw-ílé mátì
NEG 1PL quickly-PST.NEG 1PL drink-PST water 'we have not quickly drunk water'
b. à hí hàtl-àngì hí dy-ílé vúswà
NEG 1PL quickly-PST.NEG 1PL eat-PST porridge
'we have not quickly eaten porridge'
c. *a hi hatlangi hi nwile mati hi nkarhi wolowo
'(intended) we did not quickly drink water at that time'
d. $*$ a hi hatlangi hi dyile vuswa hi nkarhi wolowo
'(intended) we did not quickly eat porridge at that time' 
The past negative without the -ile suffix is ambiguous (27a) unlike affirmative sentences. Both the simple past phrase 'at that time' (27b) and the perfect phrase 'since yesterday' $(27 \mathrm{c})$ can be used with the past negative construction.

(27) The past negative
a. à hí hàtl-àngì hì nwà màtì
NEG 1PL quickly-PST.NEG 1PL drink water
'we did not quickly drink water' or 'we have not quickly drunk water'
b. à hí hàtl-àngì hì nwà màtì hì nkàrhí wólówó
NEG 1PL quickly-PST.NEG 1PL drink water at time that
'we did not quickly drink water at that time'
c. à hí hàtl-àngì hì nwà màtì kù sùkèlà tòlò
'we have not quickly drunk water since yesterday'
NEG 1PL quickly-PST.NEG 1PL drink water since yesterday

While the -ile suffix can co-occur with the past negative construction, the future marker $t a$ cannot co-occur with the future negative construction $(28){ }^{6}$

(28) Future negation cannot co-occur with $t a$, the future marker

*a ndzi nge hatl-i ndzi ta nwa mati

NEG 1SG FUT.NEG quickly-NEG 1SG FUT drink water

'I will not quickly drink water'

The example (29) shows that the copular verb $r i$ 'to be' is a lexical verb in the AA verb construction.

(29) Copular verb 'to be'

a. ù dzùmbà ù rí Mú-tsòngà
2sG always 2SG be CL1-tsonga
'you are always a Tsonga person'

b. và dzùmbà và rì và-fánà

3PL always 3PL be CL2-boy

'they are always boys'(or dzumba as a lexical verb: 'they relax being boys')

c. và dzùmbà và rì éntírhwènì

3PL always 3PL be at.work

'they are always at work'(or $d z u m b a$ as a lexical verb: 'they relax while at work')

In negation of the AA verb construction with ri as a lexical verb, either the AA verb or the copular verb can be negated. When the copular verb is negated, negation shows a narrow scope reading (NEG > ALWAYS) as in (30a, c, e). When the AA verb is negated, negation shows a wide scope reading (ALWAYS $>\mathrm{NEG}$ ) as in $(30 \mathrm{~b}, \mathrm{~d}, \mathrm{f})$.

(30) Copular negative (scope interaction)
2SG always 2SG NEG be CL1-student
'you are always NOT a student'
a. ù dzùmbá ú ngà rí mù-chùdènì

\footnotetext{
${ }^{6}$ A reviewer suggested that the asymmetry between $t a$ and -ile can be explained if we assume that the -ile suffix can encode perfect aspect on a lexical verb, but tense (such as $t a$ ) cannot be marked on a lexical verb; such a system is similar to the Swahili system (Gibson and Marten 2015).
} 


$\begin{array}{lll}\text { b. à wú dzúmb-í ú rí mú-chúdéní } & \text { ALWAYS > NEG } \\ \text { NEG 2SG always-NEG 2SG be CL1-student } & \\ \text { 'you are not always a student' } & \text { NEG > ALWAYS } \\ \text { c. ú dzúmbá á ngá rí kónà } & \\ \text { 3SG always 3SG NEG be there } & \text { ALWAYS > NEG } \\ \text { 'she is always NOT there' } & \\ \text { d. 3SG ngà dzúmb-í á rí kóná } & \text { NEG > ALWAYS } \\ \text { 'she is not always-NEG 3SG be there } & \\ \text { e. vá dzúmbá vá ngá rí vánà } & \text { ALWAYS > NEG } \\ \text { 3PL always 3PL NEG be children } & \\ \text { 'they are always NOT children' } & \\ \text { à và dzúmb-í vá rí váná } & \end{array}$

The negation of modal verbs (cannot or must not) in the AA verb construction also targets the AA verb (31a, 32a), and not the lexical verb (31b, 32b).

(31) CANNOT
a. à ndzí ngé hàtl-ì ndzí nwà màtì
NEG 1 SG CAN quickly-NEG 1 SG drink water
'I cannot quickly drink water'
b. *ndzi hatla a ndzi nge nwi mati

(32) MUST NOT
a. à ndzí fánéláng-ì kù hàtlà ndzí nwá mátí NEG 1SG MUST-NEG KU quickly 1SG drink water 'I must not quickly drink water'
b. *ndzi hatla a ndzi fanelangi ku nwa mati

\subsection{Other constructions: relative clauses and wh-questions}

The relative clause marker in Xitsonga relative clauses agrees with the head of the relative clause. The lexical main verb of the relative clause is then marked with the $-k a$ suffix as in (33a). When used in a relative clause, the $-k a$ suffix attaches to the AA verb (33b, d), not the lexical verb (33c).

(33) Relative clause suffix is marked on AA verbs
a. và-nhù là-và và nwà-kà màtì vá hàny-ílé kàhlé
CL2-man REL-CL2 SM2 drink-REL water SM2 health-STATIVE well 'people who drink water are healthy'
b. và-nhù là-và dzùmbà-kà và nwà màtì vá hàny-ílé kàhlé CL2-man REL-CL2 always-REL SM2 drink water SM2 health-STATIVE well 'people who always drink water are healthy'
c. *vanhu lava dzumba va nwaka mati va hanyile kahle
d. váná lá-vá hátlá-ká vá dyá vúswà vá lává kú tlángá éhàndlè children REL-CL2 quickly-REL SM2 eat porridge SM2 want to play outside 'children who quickly eat porridge want to play outside'


Subject wh-questions in Xitsonga, as in other southern Bantu languages, require the question word (mani 'who') to be fronted (see Zerbian 2007: 69-71 for similar discussions). The verb of the subject wh-question is also marked with the suffix $-k a$. This suffix $-k a$ must attach to the AA verb (34a, d), and cannot be attached to the lexical verb (34b), nor can it appear on both verbs $(34 \mathrm{c})$.

(34) Subject wh-question

a. í mánì à hàtlà-kà à nwà màtì? FOC who 3SG quickly-KA 3SG drink water 'who does quickly drink water?'

b. $\quad *$ i mani a hatla a nwaka mati?

c. *i mani a hatlaka a nwaka mati?

d. í mánì á hàtlà-kà à dyà vúswà? FOC who 3SG quickly-KA 3SG eat porridge 'who does quickly eat porridge?'

In situ object wh-questions do not require the $-k a$ suffix on the verb (35a). When the object wh-word is fronted, the main clause shows the morphosyntax of a relative clause with the suffix - $k a$. A resumptive pronoun appears in the original place of the fronted wh-words. This $-k a$ suffix attaches to the AA verb (35b), and not the lexical verb (35c). The same pattern is shown when the wh-word 'which one' is fronted as in (35d).

(35) object wh-question
a. xáná Bàlóyì ú hátlá á nwá yíní?
Q Baloyi SM3SG quickly SM3SG drink what 'what does Baloyi quickly drink?'
b. í yíní lé-xí Bàlóyì á hàtlà-kà à xì nwà? FOC what REL-CL7 Baloyi SM3SG quickly-REL SM3SG OMCL7 drink 'what is it that Baloyi quickly drinks?'
c. *i yini lexi Baloyi a hatla a xi nwaka?
d. hí wáhì lá-má Bàlóyì á hàtlà-kà à mà nwà? FOC which.one REL-CL6 Baloyi SM3SG quickly-REL SM3SG OMCL6 drink 'Which one does Baloyi quickly drinks?'

In this section, morphosyntactic processes that target the AA verb were presented. Tense, aspect and mood markers all attach to the AA verb. In negative sentences, the -ile suffix may attach to the lexical verb and produce a perfect reading; simple past is not a possible interpretation when the negative perfect/past marker co-occurs with the -ile suffix. When the lexical verb is the copular verb $r i$ 'to be', negation can target either the AA verb or the copular verb. These alternatives create a scope interaction in the interpretation of the sentences. The $k a$ suffix that appears in relative clauses and wh-constructions also targets AA verbs.

The patterns in this section suggest that AA verbs are placed in a syntactically higher position than lexical verbs. The pattern in which the negative suffix can attach to AA verbs or lexical verbs further suggests that AA verbs are in an even higher position when the negative suffix is attached to it; it probably shows a type of NEG raising. In the following section, morphosyntactic phenomena that target the lexical verb will be presented. 


\section{Lexical verb as a target}

In this section, we examine morphosyntactic processes that target the lexical verb in AA constructions: object marker, verbal extensions (applicative, reciprocal, causative and passive) and reflexive marker. Data that is reported here includes the doubling of the object marker and that of the causative and passive markers.

\subsection{Position of object pronoun and reflexives}

In AA constructions, the object pronoun is placed between the second subject agreement and the lexical verb (36a). The object pronoun cannot be placed before the AA verb (36b), but it may be doubled (36c). The doubling of object pronouns adds an emphatic meaning to the sentence targeting the object pronoun (translated as 'definitely' in the examples in (36)). In (36d-h), each example has a pair of sentences: object marker before the lexical verb and the doubling of the object marker.

(36) Object pronoun

a. ndzì hàtlà ndzí byí dyà
1SG quickly 1SG OM13 eat
'I quickly eat it (it = vuswa)'
b. *ndzi byi hatla ndzi dya
c. ndzì byí hátlá ndzí byì dyà
1SG OM13 quickly 1SG OM13 eat
'I definitely quickly eat it'
d. vá dzúmbá vá ndzí vònà
3PL always 3PL OM1sG see
'they always see me'
vá ndzí dzúmbá vá ndzí vònà
'they definitely always see me'
hì hàtl-1́lé hí n'wí vítáná
1PL quickly-PST 1PL OM3sG call
'we quickly called her'
hì n'wí hàtlíle hí n'wi vítáná
'we definitely quickly called her'
ndzì tà hàtlà ndzí n'wí vóná
1sG FUT quickly 1sG OM3sG see
'I will quickly see her'
ndzì tà n'wì hátlá ndzí n'wí vóná
'I will definitely quickly see her'
ndzì ngá hàtlà ndzí n'wí vònà
1sG CAN quickly 1sG OM3sG see
'I can quickly see her'
ndzì ngá n'wí hátlá ndzí n'wí vóná
'I can definitely quickly see her'




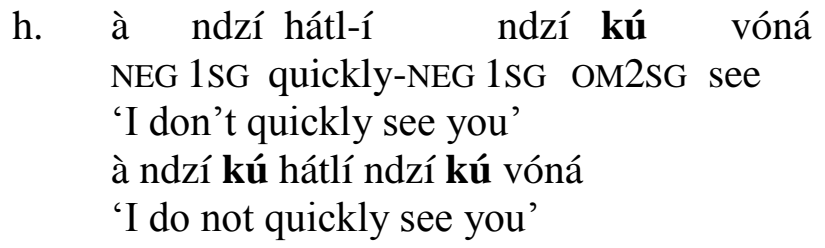

When the object marker is doubled (37a), it cannot occur with the modal verb fanele $k u$ 'must' (37b). For reasons beyond the scope of this paper, the doubling is not possible when the lexical verb xeweta 'to greet' is used by itself (37d). However, the addition of the locative adjunct exikolweni 'at school' allows object markers to double (37e).

(37) Exception to the object doubling
a. ndzì fànèlè kù hàtlà ndzí n'wí hlóngórísá
1SG MUST quickly $1 \mathrm{SG}$ OM3SG chase
'I must quickly chase him'
b. *ndzi fanele ku n'wi hatla ndzi n'wi hlongorisa
c. ndzì hàtlà ndzí kú xéwétá
1SG quickly 1SG OM2SG greet
'I quickly greet you'
d. *ndzi ku hatla ndzi ku xeweta
e. ndzì kù hátlá ndzí kú xéwétá éxíkólwénì
'I definitely quickly greet you at school'

The reflexive prefix $t i$ - also attaches to the lexical verb $(38 \mathrm{a}, \mathrm{b})$. The reflexive prefix cannot attach to the AA verb (38c), nor can it occur on both verbs (38d).

(38) Reflexive prefix $t i$ - attaches to the lexical verb
a. vá dzúmbá vá tí-tsákísá
3PL always 3PL REFL-please
'they always please themselves'
b. vá hátlá vá tí-khúmbà
3PL quickly 3PL REFL-touch
'they quickly touch themselves'
c. *va ti-dzumba va tsakisa
d. *va ti-dzumba va ti-tsakisa

\subsection{Verbal extensions}

Xitsonga has verbal extensions that change the argument structure of the lexical verb. The applicative suffix -el-, when attached to the lexical verb (39a), for example, makes the verb take the benefactive object mánáná 'mother'. In AA constructions, this suffix does not attach to the AA verb (39b), nor can it double as in (39c). When the AA verb hatla 'quickly' (or any other AA verbs) functions as a lexical verb, the addition of the applicative suffix is possible: hatlela 'to move fast' (39d), with the $k u$ clause that denotes purpose; the purpose clause part is different from type 2 in (3b). Doubling of the subject agreement is not possible when hatla is a lexical verb $(39 \mathrm{e})$. 
(39) Applicative -el-
a. ndzì hàtlà ndzí nw-él-á mánáná mátí
1SG quickly $1 \mathrm{SG}$ drink-APPL-FV mother water
'I quickly drink water for mother'
b. *ndzi hatl-el-a ndzi nwa manana mati
c. *ndzi hatl-el-a ndzi nw-el-a manana mati
d. ndzì hàtl-èl-à kù nwá mátí
1SG move.fast-APPL-FV INF drink water
'I move fast in order to drink water'
e. *ndzi hatl-el-a ndzi nwa mati

The reciprocal suffix - an- attaches to the lexical verb (40a), and not the AA verb (40b). The verb hatlana with the reciprocal suffix has a lexicalised meaning: 'simultaneously' (40c). This lexicalised verb hatlana is also an AA verb (40d).

(40) Reciprocal-an-
a. hi hatla hi xewet-an-a ${ }^{7}$
1PL quickly 1PL greet-RECP-FV
'We quickly greet each other'
b. *hi hatlana hi xeweta
c. hì hàtlànà kù nwá mátí
1PL simultaneously INF drink water
'we simultaneously drink water'
d. hì hàtlànà hí bán-án-á
1PL simultaneously 1PL hit-RECP-FV
'we simultaneously hit each other'

The passive suffix in Xitsonga is attached to the lexical verb $(41 \mathrm{a}, \mathrm{c})$. It is ungrammatical to attach the passive suffix to the AA verb $(41 \mathrm{~b}, \mathrm{~d})$.

(41) Passive suffix - iw-
a. mátí má hátlá má nw-íw-á hí vá-nhù water SM6 quickly SM6 drink-PASS-FV by CL2-man 'water is quickly drunk by people'
b. *mati ma hatl-iw-a ma nwa hi vanhu
c. vúswá byí hátlá byí dy-íw-á hí vá-fánà porridge SM13 quickly SM13 eat-PASS-FV by CL2-boy 'porridge is quickly eaten by boys'
d. *vuswa byi hatl-iw-a byi dya hi vafana

\footnotetext{
${ }^{7}$ The second author reports that a monosyllabic lexical verb bá 'to beat' is realised with two reciprocal suffixes. We hypothesise that the doubling of the reciprocal suffix is due to some type of three-syllable minimal word requirement in Xitsonga.

a. hì hàtlà hí b-án-án-á

1PL quickly 1PL beat-RED-RECP-FV

'We quickly beat each other'

Note that this templatic restriction is not observed with the passive (41a) and the causative (42a).
} 
The causative suffix - $i s$ - attaches to the lexical verb (42a), and it does not attach to the AA verb (42b). When hatla is a lexical verb, the causative suffix can attach to it (42c). Doubling of the subject agreement is not allowed because it will result in a structure, which is ungrammatical (42b).

(42) Causative suffix -is-

a. ndzí hàtlà ndzí nw-ís-á tí-hòmú mátí

1sG quickly 1SG drink-CAUS-FV CL10-cow water

'I quickly make cattle drink water'

b. *ndzi hatl-is-a ndzi nwa tihomu mati

c. ndzì hàtl-ìs-à kù nwá mátí

1SG move.fast-CAUS-FV INF drink water

'I make a fast move to drink water' (= 'I quickly drink water')

The passive suffix can be doubled; it attaches to the lexical verb and to the AA verb (43). Likewise, the causative suffix can also double (44). However, the doubling of the passive or causative suffix does not have any emphatic effects on the meaning of the sentences, unlike the doubling of object pronouns.

(43) Doubling of the passive suffix

a. mátí má hátl-íw-á má nw-íw-á hí vá-nhù (lókó kú hísá ngópfù) water SM6 quickly-PASS-FV SM6 drink-PASS-FV by CL2-man when SM15 hot much 'water is quickly drunk by people (when it is too hot)'

b. vúswà byí hátl-íw-á byí dy-íw-à hì và-fánà porrdige SM13 quickly-PASS-FV SM13 eat-PASS-FV by CL2-boy 'porridge is quickly eaten by boys'

(44) Doubling of the causative suffix
a. ndzì hàtl-ìs-à
ndzí nw-ís-á
tí-hòmù màtì
1SG quickly-CAUS-FV 1SG drink-CAUS-FV CL10-cow water
'I quickly make cattle drink water'

\section{Yes-no questions, comparatives and stacking}

The Q-morpheme for a yes-no question in Xitsonga is xana. Adding the Q-morpheme to a declarative sentence turns it into an interrogative sentence (45).

(45) Yes-no questions: the position of the question morpheme xana

a. xáná ú hàtlà ú nwá mátí?

Q 2SG quickly 2SG drink water

'Do you drink water quickly?'

b. xáná ú hàtlà ú dyá vúswá?

Q 2SG quickly 2SG eat porridge

'Do you eat porridge quickly?'

c. xáná ú dzúmbá ú vóná ndlópfú é Krúgèr?

Q 2SG always 2SG see elephant in Kruger

'Do you always see an elephant in the Kruger?'

(or dzumba as a lexical verb 'Do you relax and see an elephant in the Kruger?') 
The position of the Q-morpheme is relatively free. In addition to the front of a sentence, the Q-morpheme can be placed after the AA verb (46a), after the lexical verb (46b) or at the end of a sentence (46c). However, the morpheme xánà cannot be placed immediately after the subject agreement markers $(46 \mathrm{~d}$, e), which suggests that subject markers in Xitsonga are really preverbal prefixes, even though they are written disjunctively. This distributional restriction of xánà suggests that the agreement marker and the following verb form a constituent that cannot be separated.

(46) Variable position of xánà

a. ù hàtlà xáná ú nwá màtí?

b. ù hàtlà ú nwá xáná màtí?

c. ù hàtlà ú nwá mátí xànà?

d. *u xana hatla u nwa mati

e. *u hatla u xana nwa mati

'Do you quickly drink water?'

A canonical comparative sentence is shown in (47a). The AA verb can also be used in constructions such as comparative (47b), superlative (47c) and equative (47d). The AA verb precedes the lexical verb (either stative such as lèhílè 'tall' $(47 \mathrm{~b}, \mathrm{~d})$ or the copular verb $r i$ 'to be' (47c)). In comparative sentences, dzúmbà can only be interpreted as an AA verb, not as a lexical verb.

(47) Comparative, superlative or equative
a. Bàlóyì ú léh-ílé kú húndzà Chàùkè
Baloyi SM3SG tall-STAT INF EXCEED Chauke
'Baloyi is taller than Chauke'
b. Bàlóyì ú dzúmbá á léh-ílé kú húndzà Chàùè̀
Baloyi SM3SG always SM3SG tall-STAT INF EXCEED Chauke
'Baloyi is always taller than Chauke'
c. Bàlóyì ú dzúmbá á rí lónkúlú éká hìnkwà-vò
Baloyi SM3SG always SM3SG be big of all-CL2
'Baloyi is always the biggest of all'
d. Bàlóyí nà Chàúké vá dzúmbá vá léh-ílé kú rìng-àn-à
Baloyi and Chauke SM3PL always SM3PL tall-STAT INF same-RECP-FV
'Baloyi and Chauke are always the same (height)'

Stacking of adverbial auxiliaries is also possible. In (48), examples with two adverbial auxiliaries (hatla 'quickly' and engeta 'again') are shown. The order of these auxiliaries determines different scopes of AA verbs. In (48a), hatla has a wider scope. The sentence emphasises the quickness in which water is being drunk compared to the recurrence of the drinking event. The AA verb engeta has a wider scope in (48b), in which the emphasis is on the recurrence of the drinking event rather than the quickness of the drinking of the water.

(48) Stacking of two adverbial auxiliaries
a. ndzì hàtlà ndzí éngétá ndzí nwà màtì
1SG quickly $1 \mathrm{SG}$ again SM1SG drink water
'I quickly drink water again.' 


\section{b. ndzì èngètà ndzí hátlá ndzí nwà màtì 1SG again 1SG quickly SM1SG drink water 'I again quickly drink water'}

Stacking of three adverbial auxiliaries is also possible. As shown in (49), the stacking does not necessarily result in a change of meaning. However, not all orders are possible. The auxiliary verb $k u$ tlhela 'once' cannot be the last of the three verbs (49e, f). A study of restrictions regarding surface linearisation of AA verbs is a topic for future work.

(49) Stacking of three adverbial auxiliaries
a. ndzì tlhèlà ndzí hátlá ndzí èngètà ndzì nwà màtì 1SG once 1SG quickly $1 \mathrm{SG}$ again $1 \mathrm{SG}$ drink water 'Once again, I quickly drink water again'
b. ndzì hàtlà ndzí tlhélá ndzí éngétà ndzì nwà màtì
c. ndzì tlhèlà ndzí éngétá ndzí hàtlà ndzì nwà màtì
d. ndzì èngètà ndzí tlhélá ndzí hàtlà ndzì nwà màtì
e. *ndzi hatla ndzi engeta ndzi tlhela ndzi nwa mati
f. $\quad *$ ndzi engeta ndzi hatla ndzi tlhela ndzi nwa mati

Extensions can also be stacked: the passive marker follows the applicative marker. In such a case, either the verbal object mati 'water' (50a) or the applicative argument manana 'mother' (50b) can be the subject of the passivised lexical verb.

(50) Applicative - Passive
a. mátí má hátlá water SM6 quickly SM6 drink-APPL-PASS-FV mother 'Water is quickly drunk for mother'
b. mánáná ú hátlá á nw-ér-íw-á mátí mother SM3SG quickly SM3SG drink-APPL-PASS-FV water 'Mother is quickly drunk water for'

In the passive sentences, doubling of the passive suffix is also acceptable as shown in (51). However, the doubling does not result in emphasising any parts of the sentence.

(51) Doubling the passive suffix
a. mátí má hátl-íw-á
má nw-ér-íw-á
mánánà
water SM6 quickly-PASS-FV SM6 drink-APPL-PASS-FV mother
'Water is quickly drunk for mother'
b. mánáná ú hátl-íw-á á nw-ér-íw-á mátí mother SM3SG quickly-PASS-FV SM3SG drink-APPL-PASS-FV water 'Mother is quickly drunk water for'

The causative marker precedes the applicative marker (52a). When an AA verb is added to the sentence (52b), the doubling of the causative suffix is possible (52c). Note that causative precedes applicative, whereas passive follows applicative. While the passive marker and the causative marker have a different syntactic location, their doubling is grammatical. 
(52) Causative - applicative
a. ndzí dy-ís-él-á mánáná n'wáná xínkwà
1SG eat-CAUS-APPL-FV mother child bread
'I make a child eat bread on behalf of mother'
b. ndzì hàtlà ndzí dy-ís-él-á mánáná n'wáná xínkwà
1SG quickly 1SG eat-CAUS-APPL-FV mother child bread
'I quickly make a child eat bread on behalf of my mother'
c. ndzì hàtl-ìs-à ndzí dy-ís-él-á mánáná n'wáná xínkwà
1SG quickly-CAUS-FV 1SG eat-CAUS-APPL-FV mother child bread

\section{Discussion and conclusion}

In this paper, we presented the distribution of AA verbs in Xitsonga. Various morphosyntactic structures suggest that AA verbs and lexical verbs show complementary distribution. The table in (53) is a summary of all the patterns. Parentheses show the loci of interest for future research regarding AA constructions in Xitsonga. A cross-linguistic study of other southern Bantu languages such as TshiVenda, Setswana, SiSwati, Sotho, isiZulu, isiXhosa, etc. is also warranted.

(53) Summary of morphosyntactic characteristics of AA verbs and lexical verbs

\begin{tabular}{|c|c|c|c|}
\hline & \multicolumn{2}{|l|}{ AA verb } & lexical verb \\
\hline tense & \multicolumn{2}{|l|}{ yes } & no \\
\hline aspect & \multicolumn{2}{|l|}{ yes } & $\begin{array}{l}\text { no } \\
\text { (yes, in perfect negation) }\end{array}$ \\
\hline $\operatorname{mood}$ & \multicolumn{2}{|l|}{ yes } & no \\
\hline negation & \multicolumn{2}{|l|}{ yes } & $\begin{array}{l}\text { no } \\
\text { (yes, in copular negation) }\end{array}$ \\
\hline relative marker & \multicolumn{2}{|l|}{ yes } & no \\
\hline wh-subject question & \multicolumn{2}{|l|}{ yes } & no \\
\hline applicative (-el-) & \multicolumn{2}{|l|}{ no } & yes \\
\hline reciprocal (-an-) & \multicolumn{2}{|l|}{ no } & yes \\
\hline \multirow[t]{2}{*}{ reflexive (ti-) } & \multicolumn{2}{|l|}{ no } & yes \\
\hline & by itself & if doubled & \\
\hline passive (-iw) & no & yes & yes \\
\hline causative (-is-) & no & yes & yes \\
\hline object pronoun & no & $\begin{array}{l}\text { yes } \\
\text { (for emphasis) }\end{array}$ & yes \\
\hline
\end{tabular}

\section{Acknowledgements}

We would like to thank two anonymous reviewers for their helpful comments. A special thanks to Clementinah Burheni, who assisted us in marking tone in the examples in the paper. We also thank the audience at SAMWOP-3, especially Andrew van der Spuy, Jochen Zeller, Kristina Riedel and William Bennett.

\section{References}

Anderson, G.D. 2011. Auxiliary verb constructions in the languages of Africa, Studies in African Linguistics 40: 1\&2: 1-409. 
Baumbach, E.J.M. 1987. Analytical Tsonga Grammar. Pretoria: UNISA.

Cole, D.T. 1955. An Introduction to Tswana Grammar. London: Longmans and Green.

Cuenod, R. 1967. Tsonga-English dictionary. Braamfontein: Sasavona.

Doke, C.M. 1992. Textbook of Zulu Grammar. 6th ed. Cape Town: Maskew, Miller and Longman.

Gibson, H. and L. Marten. 2015. Variation and grammaticalisation in Bantu complex verbal constructions: The dynamics of information growth in Swahili, Rangi and siSwati. In Léa Nash and Pollet Samvelian (Eds.) Approaches to Complex Predicates. Leiden: Brill.

Henderson, B. 2013. Agreement and person in anti-agreement. Natural Language and Linguistic Theory 31(2): 453-481.

Marivate, C.T.D., D.I. Mathumba and X.E. Mabaso. 1990. (revised ed.) Tsonga: the only study guide for TSG202-H. UNISA.

Schneider-Zioga, P. 2007. Anti-agreement, anti-locality and minimality: the syntax of disclosed subjects. Natural Language and Linguistic Theory 25: 403-446.

Taljaard, P.C., J.N. Khumalo and S.E. Bosch. 1991. Handbook of siSwati. Pretoria: J.L. Van Scheik.

Zeller, J. 2006. Raising out of finite CP in Nguni: the case of fanele. Southern African Linguistics and Applied Language Studies 24(3): 255-275.

Zerbian, S. 2007. A first approach to information structuring in Xitsonga/Xichangana. SOAS Working Papers in Linguistics Vol. 15: 65-78.

Ziervogel, D. and E.J. Mabuza. 1976. A grammar of the Swati language. Pretoria: J.L. van Schaik. 


\section{Appendix}

The following AA verbs are not included in Cuenod (1967). The data is by the second author.

a. ku kánga

à ngà kángá á fíká énhléngélétánènì

3SG PST never 3SG arrive at.the.meeting

'He never arrived at the meeting'

b. ku khánga

ú khángá á b-íwá hì swì-gèvèngà

3SG once 3SG beat-PASS by CL8-criminal

'He was once beaten by criminals'

c. ku vhèla

ú tá vhélá á kúkúlá kámárá rá vánà

3SG FUT have.to 3SG sweep room of children

'He will have to sweep the children's room'

d. ku nàmba

ù tà nàmbà ú n'wí yímélá á vúyá

2SG FUT have.to 2SG 3SG.OBJ wait.for to return

'You will have to wait for him'

e. $\mathrm{ku} \mathrm{za}$

ú tá zá á n'wí bà

3SG FUT end.up 3SG 3SG.OBJ beat

'He will end up beating him'

f. ku zànga

á ngá zángá á xává móvhá

3SG PST never 2SG buy car

'He has never bought a car'

g. ku phóse

ú phósé kú lúmá hí nyóká

3SG nearly INF be.bitten by snake

'He was nearly bitten by a snake' 